\title{
Problematics of Direct Elections for Local Head after the Amendment of the 1945 Constitution of the Republic of Indonesia
}

\author{
M. Tauchid Noor ${ }^{1} \&$ Kamarudin ${ }^{2}$ \\ ${ }^{1}$ Post Graduate Program, Kanjuruhan University of Malang, Indonesia \\ ${ }^{2}$ Faculty of Law, Hang Tuah University, Surabaya, Indonesia \\ Correspondence: Kamarudin, Faculty of Law, Hang Tuah University, Jalan Arif Tahman Hakim No. 150 \\ Surabaya 60111, Indonesia. Tel: 62-813-9290-8729. E-mail: kamarudin@hangtuah.ac.id
}

Received: May 8, $2017 \quad$ Accepted: May 15, $2017 \quad$ Online Published: June 23, 2017

doi:10.5539/ass.v13n7p158 URL: https://doi.org/10.5539/ass.v13n7p158

\begin{abstract}
The amendment of the 1945 Constitution sets that governors, regents, and local mayors are democratic in their election, originally selected by the legislative assembly and latterly sifted into direct election from the people. Based on the regulation No. 22 of 2007, it states that the election of local leader and co-leader is characterized as the part of general election regime, and thus it brings impact on local election, which should run directly as well. This article examines the arising problems on local election after the amendment of the 1945 Constitution, which reveals various problematic factors in the implementation of direct election for local head has been officially established. Indonesia has run local election many times in different eras, including in Dutch colonialism, Japan colonialism, and post-independence era. In post-independence era, Indonesia also has various political climates and traditions and including Old Order, New Order, and reformation era. The alteration of this general election system aims to provide fair democracy for all people to vote for their local leaders. The implementation, however, encounters several factors and problems derived from the level of participation up to the readiness of local election committee.
\end{abstract}

Keywords: direct election, local head, direct system, amendment of the 1945 Constitution, Indonesia.

\section{Introduction}

General election is a process of electing an individual for particular political positions. Such positions are vary, including being president, representative's assembly, or local heads. In broader context, general election may refers to a process of occupying particular positions such as student president and co-president, although the term "election" is more frequently used.

General election is one attempt to persuade people by conducting rhetorical activities, public relations, public communication, lobbying, and other related activities. Although both agitation and propaganda are criticized in most democratic countries, such activities are commonly conducted by prospective candidates or politicians as political communicators in general election campaigns.

In general election, the voters are constituents, whom the prospective candidates of election offer promises and programs during campaigns. Campaigns are conducted in predetermined period of time, approaching the day of voting. After the election is done, the process of calculating the result will immediately begin. The winner of general election is based on particular conditions or system predetermined and approved by the participants and socialized to the voters.

General election in Indonesia is originally aimed to seek for representatives in House of Representatives, provincial representatives, and local/regional representatives. Since the amendment of the 1945 Constitution is established in 2002, ways of electing president and vice president are elected have changed, originally done by Peoples' Consultative Assembly shifted into direct election by public and the president election is characterized into general election regime. Among societies, the term 'general election' more frequently refers to election for legislative and president-vice president held every five years. This article examines various factors and problems of direct local election in Indonesia after the amendment of the 1945 Constitution is established. 


\section{Critical Factors of Direct Election for Local Head}

\subsection{People Participation}

In order to discuss various factors in direct local election, we need to learn from experiences of previous local elections. During such former elections, some variations of system with different historical settings are identified.

In Dutch and Japan colonial eras, the local election was held through an appointment system by central government. Historically, the implementation of general elections held since 1955 was colored by four different political climates and traditions, including Old Order, New Order, and reformation era. Although not held simultaneously with general election, local elections, particularly in New Order era, was implemented with non-participative manner and the people were even "forced" to accept the local heads appointed by the central government. During the later era, since the establishment of regulation No. 4 of 1975, the appointment system by central government was applied with several variations, including through the approval from the Ministry of Internal Affairs and Indonesia National Army headquarters. Since the establishment of regulation No. 22 of 1999, the local election was held under a representative system through House of Representatives (Tamzil, 2005). Thus, participation is practically absent. Particularly, even after the establishment of local autonomy, the people could only see, with no right to participate, how the House of Local Representatives appointed their local heads.

What interesting from these historical paths of local election in Indonesia is that neither protests nor suits of those systems and the result which make the prospective candidates lose are ever found. Such phenomena indicate that during those eras, people definitely had no right to participate as all. Those systems have deliberately omitted people participation.

Does people participation have portion in direct election? The answer of the question should be seen from several perspectives. If it refers to political participation in terms of vote, it is relatively big (the fact was found in the general election held in 2004). However, it does not seem necessarily happen when it comes to their involvement in discussion, general meeting, demonstration, and active-passive organizational membership. The similar symptoms are found in general election held in 2004 as well (Tamzil, 2005).

Tamzil (2005, p. 23) illustrated that what interesting in direct local election refers to the arising aroma of money politics. Logically, money politics tends to follow where votes are. Since the establishment of regulation No. 5 of 1974, the vote is on central government. Similarly, since the establishment of regulation No. 22 of 1999, the vote is on House of local Representatives. Conversely, since the establishment of regulation No. 32 of 2004 and the regulation No. 22 of 2007 which sets direct local election, people finally have their vote. When it is directly distributed to individual, the sense of money politics may move into those voters. Furthermore, political parties considered as "buses" for election candidates are also potential for the likelihood of money politics, although it is often denied with the notion of cost politics.

Another problem interesting to discuss in terms of the implementation of direct local election deals with candidates' credibility. The elected local head plays a big role for democratization and local development. Options of prospective local head figures become essential. Their track-records and achievements are important to be revealed in public. Unfortunately, the paradigm of hypocrite, considering that only candidates with huge capital will possibly win, recently evolves. This seems reasonable due to the huge amount the candidates must pay, including the attempt of seeking for political party and other related political tools, campaigns and the attributes, and other expenses.

The above description is just for the sake of providing general illustration that the implementation of direct local election is not an ordinary event. Local election is exclusive and essential to be carefully examined if we want to reach a better standard of democratization.

Seen from societal participation context, what needs to be measured is the involvement of public in several levels. Public do not only give their vote on the D-day but also get involved in another level of political participation. If such involvement solely refers to the voting, the local election may only be considered as pooling process of people aspiration on their favorable prospective head.

Following Shadili and Echols (1993, p. 437), the term 'pooling' is defined as a poll method (investigation of public opinion) which alternative options have been standardized, without asking for public involvement in each stage of the process of local election. Meanwhile, the system of general election (including local election) asks for political participation in each political process of general election (Asfar, 2006). That is, besides giving vote, the level of political participation is apparent by an active involvement in political discussion, both formal and informal. The further level is apparent by participation in general meeting, demonstration, and campaign. 
Another further level points to participations on political organization membership, both passive and active (known as winning team in local election).

However, public political participation is necessarily determined by the level of public interest. Some is due to the interests of power and politic, which may take optimal benefit from each hierarchy of the people. Such interests are tightly related to people position in society, both in workplace and societal environment. These interests may be due to either ideology or complementary economy.

They who see the local head as the one, either directly or indirectly, capable to improve public welfare will definitely give their participation to prospective candidates with real performance. Conversely, they who see the local election as solely for the sake of complementary economy interest may give their participation to the prospective candidates with capability to meet such interests, and in this point, the public political maturity is actually tested.

To find a credible local head, social proficiency which builds transparency and fair mechanism to prevent any money politics and moral hazard is necessary. All elements, either directly or indirectly, related to local election should avoid such practices. Besides, growing dialectics on the importance of constructing good governance is likely to happen in society. Logically, if public has already recognized the profile and track-records of prospective candidates, any money politic practices can be prevented. This point increasingly indicates that political communication, both directly and indirectly, is considered as fundamental requirement for building public political maturity.

Through transparent, equal, and fair political communication, public is expected to increasingly see the importance of voting for a credible, accountable, and potential local head for the sake of their local development. Thus, it is expected that public political participation can be better optimized in each of the stages. Such participation is significantly considered as barometer for public maturity building.

The implementation of local election which periodically turns into changes indicates the dynamic of people lives (including political lives). The political system change is inevitably associated to social changes. Following Taneko (Rijono, 2003, pp. 1-2), every individual has definitely encountered some changes basically identified as a continuous process. Dealing with those changes, many countries change their governmental system -marked by a shifting paradigm from centralist to decentralist in various rationales, purposes, forms, and dimensions.

Following Mariasmo (2001, p. 10), decentralization is required for modern government and expected to be able to create a sustainably efficient, effective, accountable, transparent, and responsive autonomy local government. Wahab and Arif $(2002$, p. 8$)$ by citing from Cooper argued that decentralization aimed to juxtapose public services with people. In accordance to Shah (1991, p. 21), this may reinforce public participation. Decentralization and participation are inseparable as like the two sides of a coin. Therefore, the policy of decentralization will be meaningful when the implementation is aimed to empower public position.

Empowering local people actually refers to public participation, and following Berns (Jalal \& Supriadi, 2001), decentralization is a driver to empower local people by involving them in public decision making. However, public participation for the development of Indonesia in New Order era is identified not optimal. The dominant and authoritative governmental regime during New Order era, according to Amnah and Subiakto (Susilo, 1997), has fettered people involvement in each of governmental process. Besides, according to Sparringa (Susilo, 1997), hegemonic government presented by New Order regime and supported by military has placed people as complementary. This, in accordance to Suryono (2001, p. 124) may emerge psychology of fear of fake awareness in society (Parera and Kekerits, 1999) or mystification and misuse of naïve awareness from public may occur as well (Paulo Freire, 2001). This may eventually create the fear of freedom from oppressed people, due to the arbitrariness of a dominant and authoritative ruler.

As being oppressed by New Order regime for three decades, it is not easy for people to have a critical awareness. Besides, education at that moment was used as a political tool for the government, and borrowing the terms from Freire (2000, pp. 30-33), our education is anti-dialogue, dehumanize, bank-style, and not referring to "conscientization". Without any critical awareness, it is difficult to make people participate. And although they finally participate, such participation is pseudo and not sincere (Freire, 2000), or not autonomous from public awareness.

Besides, the government officials of New Order regime, as identified by Loekman Soetrisno (1995, p. 207), have an exclusive definition dealing with participation different from what people commonly see. From the officials' perspective, participation is people willing to unconditionally support the government programs which design and purposes are predetermined by the government. Such definition comes with an assumption that public is 
considered as the government's subordinate and the government is dominant in determining how the development should be. As the result, the development programs keep top-down.

Hindrances in participation are strengthened, along with the development model followed by New Order government. New Order regime has based the principles of national development on economic building. By conducting economic building, it is expected to increase people welfare, decrease the level of absolute poverty, and create prosperity. It is admitted that Indonesia economic growth is impressive, as presented by Alhumami (Parera and Koekerits, 1999) that it was above 7\% per year, an achievement which never happened before. To keep it run, however, development is considered as 'new ideology', and even Lerner -as cited by Fakih (2001, p. 13)- argued that as an international ideology or even similar to 'new religion' which promises new hopes to address poverty and backwardness issues suffered by thousands people of the third world. As identified as an ideology, 'development' needs to be strongly secured and preserved. Strong security on development, according to Soetrisno (1995, p. 207), generates people's reaction which brings negative impact on the attempt of encouraging people willing to participate in development.

Such reaction, following Soetrisno (1995, pp. 207-208) includes various new traditions growing in society during that time. The tradition of being silent seems happen in public society, and the tradition of seeking for safety seems apparent in the part of government officials. The tradition of seeking for safety generates an authoritative behavior in implementing various development programs. It also makes the government not open with any dynamics of development which happen in society. Furthermore, it may cause the lack of people's willing to participate in the development. This is also related to the number of regulations which 'graves' people's willing to participate (Soetrisno, 1995).

In the context of organizing a local election, the level of public participation is primarily determined by the election system applied, the credibility of local election host, and the profile of prospective candidates. Therefore, as argued by Tamzil, the implementation of election (either central or local) seems tidal. Moreover, in the old system of local election, people participation is practically lost.

A new hope to bring people participation into life is apparent by establishing a direct local election system under the policies of decentralization (regional autonomy) which one of those has assigned the system and the process of local election toward local government, and the people may directly vote their prospective candidates. Thus, the local election is fully held by Local Election Committee without any intervention from central government.

The policies of decentralization as mentioned in Law No. 32 of 2004 on Local Government have broadened the authority of implementing regional/local autonomy by fully assigning several governmental affairs to local governments. Such affairs include general affairs, health, education, culture, farming, transportation, industry and commerce, capital investment, living environment, land affairs, cooperation, and employment. On the other hand, the authority of the central government is limited to foreign policies, defense, jurisdiction, monetary and fiscal, religion and other affairs related to national planning policies, balancing funds, national administration system, human resource empowerment, natural resource empowerment and strategic high-tech, conservation, and national standardization. Such broadening authority forces local government to accept the increasing tasks and responsibilities to be fulfilled (Nugroho, 2000).

Furthermore, another consequence of decentralization points to the process of local election. Formerly, the election of local head is conducted by the House of Representatives as the extension of the central government tool. However, as the establishment of Law No. 32 of 2004 on local government, it turns the process of local election into a direct system which allows people to vote directly so that their participation can be realized.

\subsection{The Role of Local Election Committee in the Election of Local Head}

In the system of direct local election which is indeed newly conducted, the Local Election Committee (KPUD) has a broad authority to set the electoral regulation, implement the electoral process, control and conduct electoral law enforcement. However, people have been too long confined with an electoral system fettering their participation, and to change such political system is not that easy as reversing the hands.

The social action of KPUD in realizing an interaction with public is one determinant of changing public socio-political behavior to participate in local election.

Basically, authority and role are inseparable. Authority refers to tasks an institution needs to conduct, and role refers to social functions an institution should complete based on the authority embedded. As the authority, every institution has several roles which sometimes need to complete simultaneously. Authority may automatically mean nothing when it is not well implemented by KPUD.

Dealing with that, KPUD plays some roles in local election. Roles are a set of regular behavior due to a function 
or particular position of an office or institution. Carter, cited by Najikh (2006, p. 13) asserted that roles were two-way communication processes that continuously run in order to provide better understanding of the process of an activity toward people. The scope may indicate that roles are processes of regularly communicating patterns of action/behavior (e.g., socialization, survey of behavior, public discussion, etc.) expected from either individuals or institution with public authority. Therefore, KPUD's roles refer to tasks or concrete actions KPUD needs to complete based on its authority.

Basically, KPUD's roles in local election generally follows its authority. First, KPUD needs to use its authority properly in terms of controlling electoral regulation. Dealing with that, KPUD must be able to determine the procedures of local election and implement the procedures based on electoral regulation. Particularly, KPUD must be able to implement the regulation, which includes attributing itself with regulatory stuff and then communicating the regulation to all participants of local election, stakeholders, and public. Second, KPUD must play its roles proportionally in accordance to its authority in order to compete the local electoral process. In this case, KPUD must plan and conduct all the phases of local electoral process appropriately, such as planning, socializing, cooperating with other bodies, etc. Third, KPUD must play its role according to its authority in terms of controlling and upholding the electoral law enforcement. In this case, KPUD must be able to become an independent body capable to make rules or decision based on the regulation. In concrete context, KPUD must place itself appropriately so that all the electoral regulation and decision can be accepted as a controlling reference in organizing a local election. Thus, KPUD must uphold all the applied regulation, such as: controlling, addressing, providing sanction to participants of local election, and other related stuff for the sake of implementing a participative local election. In this case, KPUD plays its role to make the legal function effective in order to create and oversee the order of local election, and also makes evaluation when it does not effectively work. KPUD can play such role in protection service for the participants of local election, public, and other stakeholders.

From those three roles, it may indicates that KPUD plays important roles in organizing a local election. This implies that KPUD has a responsibility to intensively organize a local election. Thus, KPUD's roles do not only exist in the initial phases, but also in the entire process of local election, such as registering and determining the voters, registering and determining the candidates, conducting campaigns, calculating the vote, and deciding the selected candidates.

In broad manner, those roles may refer to interpersonal roles which requires KPUD to make relation or communication, both internal and external. Such roles emerge due to KPUD's status or authority. It can be in the form of building cooperation with local election desks like police force, department of national education, department of religion, mass media, and other societal organizations and officials like religious groups, women organization, youth organization, and community organizations.

KPUD as an independent body has relation with informational roles considering KPUD as information center for local election. This role requires KPUD to seek for and provide information which is particularly related to its organizational activities. It can be socialization, public community empowerment, etc. KPUD's informational roles can be vary. This body is considered as a monitor, disseminator, and spokesman. As monitor, it acts as information acceptor and collector which should be well-functioned for organization and its environment. With this role, KPUD may lead the change, identify challenges and opportunities to develop its environment. Therefore, KPUD may see when it should provide information for making decision in local election. As an independent body, KPUD must be able to gather information dealing with internal and external activities as much as possible. As disseminator, KPUD must be able to transform information, both derived from internal and external, toward the participant and public. As spokesman, KPUD must be able to deliver information beyond the organizational environment.

Dealing with decisional role, it relates to decision making. This allows KPUD to have a formal authority which make it capable to plan important actions in local election. Besides, KPUD also functions as information center, thus, it assures that the decision KPUD made can be good for the interest of local election.

KPUD's roles include carrying responsibility, attempting to implement tasks, and realizing all the tasks based on its authority. Hence, KPUD, as an independent body potential to succeed a local election, needs to unify the commitment of its members, given that KPUD is an architect for the success of a local election.

KPUD's effective function is used as a power to optimize its members' performance and encourage people to participate. Once KPUD capable to appropriately, proportionally, and professionally play its roles, the local election may effectively run. Such effectiveness is a power to optimize its members' performance and, thus, improve the level of people participation in local election. 


\section{Problems in Direct Election for Local Head}

Public political participation in giving vote seems relatively big. However, it is not likely to happen in public discussion, general meeting, demonstration, and other related organizational memberships both active and passive. The similar tendency can be seen when it comes to general election. Furthermore, there are several problems during the process of local election with direct system.

\subsection{Money Politics}

Tamzil illustrated that one interesting matter in direct local election was the emerging circumstance of money politics (Tamzil, 2005, p. 3). Logically, money politics tend to follow where the vote are. The establishment of Law No. 5 of 1974 mentioned that the central government had the vote, while Law No. 22 of 1999 mentioned that the House of Representatives had the vote. Currently, since the establishment of Law No. 32 of 2004 on direct local election, public has the vote. When all the votes are directly distributed to each individual, money politics may move following those votes. Moreover, current political parties which act as 'bus' for prospective candidates also potential to create the likelihood of money politics, although such argument is often denied by recognizing it as cost politic.

\subsection{Profile of Prospective Candidates of Local Election}

Another interesting problem which needs to discuss dealing with the implementation of local election refers to the credibility of the candidates. The direct elected local head plays a big role for democratization and for developing his region. Thus, electing of prospective candidate profile is crucial. Particularly, track-record and performance of the prospective candidates should be crucially concerned for public. However, hypocrite paradigm, referring that only candidates with big capital may win the battle in local election, still exists up to recent year. This is reasonable, given the amount of expense the candidates must spend, from seeking for political party and other related institutions as political tool, campaign along with its attributes, and other necessary expenses.

This all description is a general illustration indicating that the implementation of direct local election is an extraordinary event. Direct local election is an idiosyncratic and crucial event which should be carefully concerned if we want to reach a better democratization.

\subsection{Public Involvement and Participation}

Measuring the direct local election success from the aspect of public participation should see the public involvement in several phases. People do not solely give their vote on the D-day, but also get involved in other political participation. Once such involvement merely refers to voting, the local election is only considered as a pooling process of public aspiration dealing with prospective candidates.

Shadili \& Echols (1993, p. 437) defined the term pooling as a poll method (investigation of public opinion) which alternative options have been standardized, without asking for public involvement in each stage of the process of local election. Meanwhile, the system of general election (including local election) asks for political participation in each political process of general election (Asfar, 2006). That is, besides giving vote, the level of political participation is apparent by an active involvement in political discussion, both formal and informal. The further level is apparent by participation in general meeting, demonstration, and campaign. Another further level of participation points to participation on political organization membership, both passive and active (known as winning team in local election).

However, public political participation is necessarily determined by the level of public interest. Some is due to the interests of power and politic, which may take optimal benefit from each hierarchy of the people. Such interests are tightly related to people position in society, both in workplace and societal environment. These interests may be due to either ideology or complementary economy.

They who see the local head as the one capable to improve public welfare (either directly or indirectly) will definitely give their participation to prospective candidates with real performance. Conversely, they who see the local election as solely for the sake of complementary economy interest may give their participation to the prospective candidates with capability to meet such interests, and in this point, the public political maturity is actually tested.

To find a credible local head, social proficiency which builds transparency and fair mechanism to prevent any money politics and moral hazard is necessary. All elements, either directly or indirectly, related to local election should avoid such practices. Besides, growing dialectics on the importance of constructing good governance is likely to happen in society. Logically, if public has already recognized the profile and track-records of 
prospective candidates, any money politic practices can be prevented. This point increasingly indicates that political communication, both directly and indirectly, is considered as fundamental requirement for building public political maturity.

Through transparent, equal, and fair political communication, public is expected to increasingly see the importance of voting for a credible, accountable, and potential local head for the sake of their local development. Thus, it is expected that public political participation can be better optimized in each of the stages. Such participation is significantly considered as barometer for public maturity building.

\subsection{The Impact of New Order Government System on Public Participation}

Public participation for the development of Indonesia is not optimally realized during New Order era. This dominant and authoritative governmental regime, according to Amnah and Subiakto (Susilo, 1997) has fettered public involvement in each of governmental processes. In addition, according to Sparringa (Susilo, 1997), hegemonic government presented by New Order regime and supported by military has placed people as complementary. This, in accordance to Suryono (2001, p. 124) may emerge psychology of fear of fake awareness in society (Parera and Kekerits, 1999) or mystification and misuse of naïve awareness from public may occur as well (Paulo Freire, 2001). This may eventually create the fear of freedom from oppressed people, due to the arbitrariness of a dominant and authoritative ruler.

As being oppressed by New Order regime for three decades, it is not easy for people to have a critical awareness. Besides, education at that moment was used as a political tool for the government, and borrowing the terms from Freire (2000, pp. 30-33), our education is anti-dialogue, dehumanize, bank-style, and not referring to "conscientization". Without any critical awareness, it is difficult to make people participate. And although they finally participate, such participation is pseudo and not sincere (Freire, 2000), or not autonomous from public awareness.

Moreover, the government officials of New Order regime, as identified by Loekman Soetrisno (1995, p. 207), have an exclusive definition dealing with participation different from what people commonly see. From the officials' perspective, participation is people willing to unconditionally support the government programs which design and purposes are predetermined by the government. Such definition comes with an assumption that public is considered as the government's subordinate and the government is dominant in determining how the development should be. As the result, the development programs keep top-down.

Hindrances in participation are strengthened, along with the development model followed by New Order government. New Order regime has based the principles of national development on economic building. By conducting economic building, it is expected to increase people welfare, decrease the level of absolute poverty, and create prosperity. It is admitted that Indonesia economic growth is impressive, as presented by Alhumami (Parera and Koekerits, 1999) that it was above 7\% per year, an achievement which never happened before. To keep it run, however, development is considered as 'new ideology', and even Lerner -as cited by Fakih (2001, p. 13)- argued that as an international ideology or even similar to 'new religion' which promises new hopes to address poverty and backwardness issues suffered by thousands people of the third world. As identified as an ideology, 'development' needs to be strongly secured and preserved. Strong security on development, according to Soetrisno (1995, p. 207), generates people's reaction which brings negative impact on the attempt of encouraging people willing to participate in the development.

Such reaction, following Soetrisno (1995, pp. 207-208) includes various new traditions growing in society during that time. The tradition of being silent seems happen in public society, and the tradition of seeking for safety seems apparent in the part of government officials. The tradition of seeking for safety generates an authoritative behavior in implementing various development programs. It also makes the government not open with any dynamics of development which happen in society. Furthermore, it may cause the lack of people's willing to participate in the development. This is also related to the number of regulations which 'graves' people's willing to participate (Soetrisno, 1995).

\subsection{The Impact of Decentralization}

The implementation of local election periodically turning into changes indicates the dynamic of people lives (including political lives). The political system change is inevitably associated to social changes. Following Taneko (Rijono, 2003, pp. 1-2), every individual has definitely encountered some changes that are basically identified as a continuous process. Dealing with those changes, many countries change their governmental system -marked by a shifting paradigm from centralist to decentralist in various rationales, purposes, forms, and dimensions. 
Following Mariasmo (2001, p. 10), decentralization is required for modern government and expected to be able to create a sustainably efficient, effective, accountable, transparent, and responsive autonomy local government. Wahab and Arif (2002, p. 8), by citing Cooper's statement, argued that decentralization aimed to juxtapose public services with people. In accordance to Shah (1991, p. 21), this may reinforce public participation. Decentralization and participation are inseparable as like the two sides of a coin. Therefore, the policy of decentralization will be meaningful when the implementation is aimed to empower public position.

Empowering local people actually refers to public participation, and following Berns (Jalal \& Supriadi, 2001), decentralization is a driver to empower local people by involving them in public decision making.

A new hope to realize public participation into life is apparent by establishing a direct local election system under the policies of decentralization (regional autonomy) which one of those has assigned the system and the process of local election toward local government, and the people may directly vote their prospective candidates. Thus, the local election is fully held by Local Election Committee without any intervention from central government.

The policies of decentralization as mentioned in Law No. 32 of 2004 on Local Government have broadened the authority of implementing regional/local autonomy by fully assigning several governmental affairs to local governments. Such affairs include general affairs, health, education, culture, farming, transportation, industry and commerce, capital investment, living environment, land affairs, cooperation, and employment. On the other hand, the authority of the central government is limited to foreign policies, defense, jurisdiction, monetary and fiscal, religion and other affairs related to national planning policies, balancing funds, national administration system, human resource empowerment, natural resource empowerment and strategic high-tech, conservation, and national standardization. Such broadening authority forces local government to accept the increasing tasks and responsibilities to be fulfilled (Nugroho, 2000).

Furthermore, another consequence of decentralization points to the process of local election. Formerly, the election of local head is conducted by the House of Representatives as the extension of the central government tool. However, as the establishment of Law No. 32 of 2004 on local government, it turns the process of local election into a direct system which allows people to vote directly so that their participation can be realized.

However, what matter is that this direct local election system is newly held by giving a broad authority toward Local Election Committee (KPUD) to set the electoral regulation, implement the electoral process, control and conduct electoral law enforcement. Meanwhile, people have been too long confined with an electoral system fettering their participation, and to change such political system is not that easy as reversing the hands.

In the context of organizing a local election, the level of public participation is primarily determined by the election system applied, the credibility of local election host, and the profile of prospective candidates. Thus, as argued by Tamzil, the implementation of election (either central or local) seems tidal. In addition, with the old system of local election, people participation is practically lost.

\section{Conclusion}

General election in Indonesia applies "luber" principle which refers to "direct, general, free, and private" and "jurdil" principle which refers to "honest and fair". The amendment of the 1945 Constitution has turn the election system of president/vise-president and local head that is originally indirect into direct organized by public.

This alteration aims to provide a fair democracy for the people in electing their leaders, both in central and local government. The alteration in local election, from indirect to direct implementation, is due to several crucial factors which one of those refers to public participation and the readiness of local election committee. Direct local election encounters various problems such as: money politic, the selection of prospective candidate profiles, the level of public participation, governmental system and decentralization system.

\section{References}

Asfar, M. (2006). Pemilu dan Perilaku Memilih 1955-2004. Surabaya: Eureka dan Pusde HAM.

Freire, P. (1970). Pedagogy of the oppressed, in C.K. Wilber dan K.P. Jamesson, 1992. The Political Economy of Development and Underdevelopment. New York: MacGraw Hill Inc.

Jalal, F., \& Supriadi. (2001). Reformasi Pendidikan dalam Konteks Otonomi Daerah. Yogyakarta: Depdiknas, Bappenas dan Adicitra Karya Nusa.

Mardiasmo. (2002). Otonomi dan Manajemen Keuangan Daerah. Yogyakarta: Andi. 
Najikh, M. (2006). Partisipasi Masyarakat dalam Perspektif Teoritik dalam Sirajuddin (ed.). Hak Rakyat Mengontrol Negara. Jakarta: Yappika dan Malang: MCW.

Nugroho, T. (2000). Reformasi dan Reorientasi Kebijakan Otonomi Daerah dalam Perspektif Hubungan Pemerintah Pusat-Daerah. Jurnal Administrasi Negara, 1(2), 13.

Ngusmanto (2016). Pilkada 2015 and Patronage Practice among Bureaucrat in West Kalimantan, Indonesia. Asian Social Science, 12(9), 236-243. http://dx.doi.org/10.5539/ass.v12n9p236

Parera, F. M., \& Koekerits. (1999). Masyarakat Versus Negara, Paradigma Baru Membatasi Dominasi Negara, Debat Publik Seputar Paradigma Kehidupan Bermasyarakat. Jakarta: Penerbit Kompas.

Rijono, N. (2003). Partisipasi Masyarakat dalam Pendidikan: Kajian Fenomenologis Makna Partisipasi bagi Masyarakat Etnis Kutai. Disertasi pada Program Pascasarjana Universitas Merdeka Malang.

Sadily, H., \& Echols, J. M. (1992). Kamus Bahasa Inggris - Indonesia. Jakarta: Gramedia.

Shah, A. (1999). Balances, Accountability and Responsiveness: Lesson About Decentralization. Washington D.C. USA: World Bank.

Soetrisno, Lukman. (1995). Menuju Masyarakat Partisipatif. Yogyakarta: Kanisius.

Suryono, Agus. (2001). Teori dan Isu Pembangunan. Malang: UM Press.

Susilo, I. B. (1997). Masyarakat dan Negara, Kado untuk Prof. Soetandyo Wignjosoebroto, MPA. Surabaya: Airlangga University Press.

Tamzil, M.H. (2005, June 10). Pilkada dan Kedewasaan Politik Masyarakat. Suara Merdeka, Rubrik Wacana.

*** Undang-Undang Dasar 1945 Amandemen

*** Undang-Undang Nomor 22 tahun 1999 tentang Pemerintahan Daerah

*** Undang-Undang Nomor 22 tahun 2007 tentang Penyelenggara Pemilihan Umum.

\section{Copyrights}

Copyright for this article is retained by the author(s), with first publication rights granted to the journal.

This is an open-access article distributed under the terms and conditions of the Creative Commons Attribution license (http://creativecommons.org/licenses/by/4.0/). 